\title{
Apresentação
}

\section{O AVANÇO DO CONSERVADORISMO NAS POLÍTICAS CURRICULARES}

O dossiê temático da Revista Teias em parceria com a Associação Brasileira de Currículo (ABdC), no ano de 2016, apresenta como tema central O AVANÇO DO CONSERVADORISMO NAS POLÍTICAS CURRICULARES. O propósito que nos mobilizou como organizadores foi o de reunir e integrar em um dossiê pesquisas atuais do/no campo do currículo que evidenciassem como diferentes discursos sociais vêm se articulando e ganhando força para interferir nas relações da escola, do conhecimento, do trabalho e da formação docente, inclusive formulando prescrições curriculares e/ou de outras iniciativas completamente dissonantes com o que tem constituído o debate público e democrático sobre educação.

O atual cenário político e social tem remetido à visível intensificação de posições muito diferentes entre si, reflexo dos diversos grupos que se mobilizam e se articulam na tentativa de ganhar espaço e força em diferentes áreas da vida social e muito expressivamente na educação. São, em geral, discursos que operam em uma lógica conservadora que mesmo quando associados a outros discursos sociais de matriz democrática como a igualdade, justiça social, cidadania, etc., recompõem discursos superados.

Como parte importante do cenário social, o contexto educacional não escapa destas estratégias e ações. Proposições curriculares e projetos de educação/escola que estão em discussão no contexto político brasileiro no momento, tais como a Base Nacional Comum Curricular e o Projeto Escola sem Partido, são exemplos de como articulações de perspectivas tão diferentes contribuem para reforçar o viés conservador no campo educacional, na medida em que defendem questões entendidas pelos pesquisadores da área da educação como verdadeiros retrocessos. Não podemos deixar de mencionar, dentre os exemplos, as últimas ações do governo Temer no que se refere às mudanças no ensino médio, por intermédio de uma Medida Provisória (MP 746/2016), ação centralizadora e autoritária que desconsidera o debate e as contribuições do campo educacional nos últimos 20 anos.

Nesse sentido, este Dossiê apresenta, nos artigos que o compõem, discussões importantes sobre políticas curriculares, discursos conservadores e trabalho docente. A partir de pesquisas 
desenvolvidas no campo da educação e, mais especificamente, no campo do currículo, os artigos apontam como perspectivas conservadoras em diferentes níveis e propostas vêm conseguindo espaços na ordem política da gestão educacional e se fortalecido nos contextos nacional ou internacional destacando também as diferentes formas de resistência a este movimento.

O primeiro artigo "Os sinos dobram por nós: o mundo, o Brasil e as narrativas curriculares dos últimos tempos", de Maria Inez Carvalho, Marcea Andrade Sales e Maria Roseli Gomes Brito de Sá, discute a emergência do espírito conservador nas narrativas curriculares. As autoras utilizam a pergunta-metáfora de um marco literário, o romance Por quem os sinos dobram? de Ernest Hemingway, para questionar as narrativas curriculares construídas a partir do final do século XX sob a perspectiva das díades. Na compreensão destas narrativas, identificam a volta das ordens discursivas finalistas e totalizantes em nome de inovações curriculares e da profunda crise nas diferentes arenas, entendidas por uma dimensão essencialista e pela manutenção de um cenário que possa garantir a desigualdade social.

$\mathrm{O}$ artigo "Democracia que temos/queremos, mediante o conservadorismo nas políticas educacionais", de Francisca Pereira Salvino e Lenilda Cordeiro Macedo, analisa os significados do termo democracia durante a reconstrução do currículo de Pedagogia, da Universidade Estadual da Paraíba, como um dos reflexos das ações promovidas pelas políticas educacionais. As autoras enfatizam os modos de participação dos diferentes sujeitos no processo de reconstrução do currículo e identificam significados diversos para o significante analisado, em função da conjuntura de forças e articulações sociais. Reconhecem ainda que as identidades construídas neste processo são afetadas de forma mais acentuada pelo avanço do conservadorismo aliado ao neoliberalismo.

O terceiro artigo "A relação entre o currículo e as avaliações externas: um estudo sobre a rede municipal de São Paulo", de Isabela Bilecki da Cunha, também analisa as ações de políticas educacionais ao tratar da participação da rede municipal de São Paulo em avaliações externas, como parte da reforma curricular no ensino fundamental. A autora apresenta a investigação em duas escolas da rede de ensino, entre os anos de 2013 e 2014, e aponta como alguns aspectos relacionados às avaliações externas adotadas acabaram por comprometer a sua contribuição para 0 aprimoramento do currículo das escolas e a proposição de políticas públicas que favorecessem o atendimento dos alunos com maiores dificuldades.

$\mathrm{O}$ quarto artigo intitulado "O discurso sobre gênero no currículo do município de Teresina: reinvenção do conservadorismo?", de Neide Cavalcante Guedes, discute o avanço dos discursos conservadores no currículo da rede municipal de educação da cidade de Teresina, por intermédio do 
Projeto de Lei 20/2016 que proíbe o debate sobre as questões de gênero nas escolas de educação básica da cidade. A autora analisa, a partir das discussões do conceito de ideologia, como as questões culturais sobre a diversidade e diferença são de fundamental importância para o currículo escolar. Aponta também para o fato da perspectiva conservadora presente nas políticas educacionais da região estar marcada por um discurso cientificista, distanciando-se das perspectivas socioculturais defendidas no campo educacional.

O quinto artigo "Discursos conservadores nas políticas curriculares: do sacerdócio à profissionalização docente", de Verônica Borges de Oliveira, contempla a investigação dos significantes sacerdócio e profissionalização docente nos discursos das políticas curriculares para a formação de professores. Trabalhando com a concepção de sujeito incompleto, a autora apresenta sua análise imersa no processo da subjetivação e da articulação política discutindo como as cadeias discursivas do sacerdócio docente se antagonizam à de profissionalização docente, na tentativa desses significantes construírem determinadas identidades docentes.

O sexto artigo chama-se "A gestão curricular local nas malhas das redes políticas em escala transnacional", de Juares da Silva Thiesen. O autor discute, a partir de uma pauta política que denomina de agenda propositiva global, a relação entre os sentidos mobilizados para a hegemonização desta agenda e os reflexos deste movimento na gestão curricular em níveis locais. Aponta como aspecto importante para a análise as quatro frentes que constituem estas mobilizações: a internacionalização do currículo, as avaliações padronizadas, a centralização curricular; e o incentivo de parcerias entre escolas públicas e o setor privado. Dessa forma, o espaço da gestão curricular ganha novos sujeitos que não atendem às mesmas demandas e finalidades que interessam à escola.

Como organizadores entendemos que este dossiê traz uma importante contribuição para a discussão sobre as políticas curriculares neste momento tão conturbado que vivemos hoje. Os artigos, no seu conjunto, enunciam, dentre outros aspectos, as relações entre a política e a educação, as arenas que constituem os territórios dos currículos, as estratégias de regulação e centralização em marcha, as implicações das avaliações de larga escala e da gestão curricular que a elas se vinculam, os embates contra-hegemônicos que atravessam o currículo, as questões culturais que envolvem a formação humana, as dimensões de formação e profissionalização docente e as questões da desigualdade social. Os textos aqui reunidos mostram como os discursos conservadores (re)emergem de múltiplas origens lugares e caminhos e que se fortalecem no tempo presente, além de explicitar a complexidade dos processos políticos que invadem a arena educacional e curricular. 
Esperamos que este dossiê contribua significativamente para as discussões sobre políticas públicas em educação e do campo do currículo em particular. Que contribua de forma efetiva visando mobilizarmos esforços de resistência e articulação no que se refere à luta dos discursos conservadores que ganham mais espaço nos espaços sociais e nas políticas curriculares.

Desejamos a todos uma boa leitura e ótimas reflexões.

Juares Thiesen Rozana Gomes de Abreu 